\title{
Aplikasi Dialogis-Klarifikatif Apologetika Paulus Terhadap Isu Gnostisisme di Jemaat Kolose Bagi Generasi Milenial yang Terpapar Zodiak Online
}

\author{
Soleman Kawangmani, \\ Sekolah Tinggi Telogi Gamaliel, Surakarta, Jawa Tengah \\ solemankawangmani@yahoo.co.id
}

DOI: https://doi.org/10.34307/b.v3i2.171

\begin{abstract}
The millennial generation is a generation that is familiar with the development of social media activities. This ease of access makes it to channel their hobby, one of which is accessing the horoscope (Zodiac). Christian faith must be able to provide proper clarification in the form of apologetics. The context of this problem is similar to the pattern of Paul's apologetics to the Colossians regarding the issue of Gnosticism. Based on this, the purpose of this research is: to find a pattern of apostle Paul's apology application to the contents of Gnosticism in the Colossians in the context of The millennial generation exposed by the Zodiac online. This paper uses a qualitative approach with descriptive theological and social research types. Data collection uses literature studies and interviews with millennials and God's servants who deal with zodiac addiction problems. This paper produces an apologetic pattern for millennials exposed to the Zodiac. These findings are described in 7 elements of dialogical-clarification apologetic patterns.
\end{abstract}

Keywords: Millennial Generation, Zodiac, Gnosticism, Apologetics

\begin{abstract}
Abstrak: Generasi milenial merupakan generasi yang akrab dengan perkembangan akses media sosial. Kemudahan akses ini menjadikan untuk menyalurkan kegemaran mereka, salah satunya adalah mengakses mengenai ramalan bintang (zodiak). Iman Kristen harus dapat memberikan klarifikasi yang tepat dalam bentuk apologetika. Konteks permasalahan ini memiliki kemiripan dengan pola apologetika Paulus pada jemaat Kolose berkaitan dengan isu gnostisisme. Berdasarkan hal tersebut tujuan dari penelitian ini adalah: menemukan suatu pola penerapan apologetika rasul Paulus terhadap isi Gnostisisme di jemaat Kolose dalam konteks generasi milenial yang terpapar Zodiak online. Tulisan ini menggunakan pendekatan kualitatif dengan jenis penelitian teologis dan sosial secara deskriptif. Pengumpulan data menggunakan kajian literature dan wawancara pada generasi milenial dan hamba Tuhan yang menangani permasalahan kecanduan zodiak. Tulisan ini menghasilkan pola apologetika bagi generasi milenial yang terpapar zodiak. Temuan tersebut dideskripsikan pada 7 elemen pola apologetika dialogis-klarifikatif.
\end{abstract}

Kata Kunci: Generasi Milenial, Zodiak, Gnostisisme, Apologetika

\begin{tabular}{llll}
\hline Article History : & Received: 14-05-2020 & Revised: 29-09-2020 Accepted:09-11-2020
\end{tabular}




\section{Pendahuluan}

Perkembangan media sosial di Indonesia semakin tidak terbendung. Penyebab utama dari ini adalah kemudahan akses setiap masyarakat melalui smartphone dengan harga yang relative terjangkau. Hal ini mendorong masyarakat dapat memanfaatkan kemudahan untuk mengkses media sosial ${ }^{1}$. Kemudahan akses media sosial ini juga dimanfaatkan oleh bagi generasi milenial untuk dapat mengakses ramalan bintang (Zodiak). Setiap hari aneka media masa dan media online menyebarluaskan Zodiak. Cara mengemas isi ramalan Zodiak yang dibuat menarik dan mendorong rasa ini tahh berhasil memikat banyak generasi milenial untuk membacanya. Independent UK mempublikasikan hasil penelitian yang mengatakan bahwa sebanyak 58\% orang Amerika berusia 18-24 tahun percaya bahwa astrologi itu ilmiah. Salah satu situs web popular yang diakses yaitu Tango ${ }^{2}$. Melihat fenomena tersebut, nampaknya Zodiak cukup digemari oleh generasi milenial pada era media sosial ini. Generasi milineal mempercayai bahwa astrologi tersebut merupakan salah satu bentuk ilmu secara ilmiah yang nantinya diharapkan dapat menjadi guide bagi hidup mereka.

Percakapan penulis dengan beberapa anak muda menunjukkan bahwa generasi milenial Kristen juga tertarik pada ramalan zodiak bahkan memperoleh manfaat. Mahasiswa bernama Yohanatan mengatakan bahwa ia sudah mengenal Zodiak sejak masih di SMA. Bermula dari membaca Zodiak di koran, kemudian melakukannya secara lebih serius karena mengetahui arah hidup dan peringatan-peringatan dalam menjalani hidup sehari-hari ${ }^{3}$. Tery yang saat ini sedang berkuliah juga berkata mulanya hanya iseng membaca zodiak, tetapi kemudian ada rasa ingin tahu yang lebih dan mendapatkan arahan serta semacam bimbingan hidup ${ }^{4}$. Demikian pula Angger (mahasiswa), pernah membaca zodiak di koran. Kemudian pada kesempatan lain melihat teman sekolah yang seiman membaca zodiak di HP. Akhirnya ikut bergabung membaca di media online. Niatnya membaca yaitu untuk mengetahui jalan hidup setiap hari ini. ${ }^{5} \mathrm{Hal}$ ini tentunya dapat dilihat dari polanya bahwa generasi milenial Kristen yang terpapar di karenakan adanya imbas dari coba-coba dan dari teman-temanya serta mengganggap bahwa zodiak merupakan hal lumrah dalam kehidupan remaja.

Fakta-fakta keterlibatan generasi milenial dengan zodiak seharusnya menjadi perhatian dan tantangan bagi gereja Tuhan, khususnya para pelayan remaja dan pemuda. Berbagai penelitian mengenai zodiak diantaranya adalah: pengembangan

\footnotetext{
${ }^{1}$ Christiany Juditha, "Fenomena Trending Topic Di Twitter: Analisis Wacana Twit \#Savehajilulung," Jurnal Penelitian Komunikasi dan Pembangunan 16, no. 2 (2015): 138-154.

2 Vika Widiastuti and Rosiana Chozanah, "Mengapa Milenial Banyak Yang Tertarik Dengan Horoskop?," Suara.Com, last modified 2019, accessed March 26, 2020, https://www.suara.com/lifestyle/2019/07/19/185000/mengapa-milenial-banyak-yang-tertarikdengan-horoskop.

3Yohanatan, beragama Kristen, aktif beribadah dan aktivis persekutuan. Wawancara, Senin, 19 Januari 2020

4 Tery, beragama Kristen dan aktif beribadah. Wawancara, Selasa, 20 Januari 2020

${ }^{5}$ Angger, beragama Kristen dan aktif beribadah. Wawancara, Selasa, 20 Januari 2020
} 
zodiak dalam aplikasi java sehingga dapat dengan mudah diakses oleh telepon genggam oleh permana, ${ }^{6}$ pembuatan aplikasi multimedia untuk ramalan bintang ${ }^{7}$, kajian wacana pada media cetak berbahasal Indonesia mengenai zodiak oleh Kurniawati ${ }^{8}$, Akulturasi zodiak sebagai hiasan motif di pura Mangkunegaran oleh afriadi ${ }^{9}$, Pembuatan buku zodiak bagi remaja 12-17 tahun yang bertujuan untuk memudakan pergaulan para remaja oleh Wibowo et $\mathrm{al}^{10}$, dan penelitian lainya. Melihat berbagai penelitian mengenai zodiak maka kekristenan harus memberikan solusi teologis untuk menjawab aplikasi dan relevansi zodiak yang menjadi trend di kalangan generasi muda. Pertimbangan teologis tersebut dapat diberikan melalui apologetika untuk dapat memberikan klarifikasi mengenenai ajaran-ajaran pada zodiak (content zodiak).

Apologetika merupakan suatu pertanggungjawaban iman sebagai wujud tanggung jawab orang Kristen. Apologetika bertujuan untuk menjelaskan sesuatu yang tidak pas dalam pandangan kekristenan dengan tujuan untuk tidak merendahkan lawan tetapi mencari kebenaran iman yang sesuai dengan prinsip kekristenan ${ }^{11}$. Berbagai penelitian apologetika juga dikembangkan sebagai wujud pertanggungjawaban iman Kristen seperti: Apologetika kepada suku jawa wongcilik $^{12}$, apologetika kreatif klarifikasi pada anak remaja usia tengah ${ }^{13}$, Apologetika pada era disrupsi secara online $^{14}$, apologetika dalam bentuk satire pada account instagram @gerejapalsu dalam kerangka kegerakan misi yang terus memperbaharui kehidupan gereja ${ }^{15}$, dan penelitian lainnya. Tentunya apologetika ini dapat diaplikasikan untuk menyatakan kebenaran Kristen mengenai zodiak. Zodiak yang berkembang dalam kehidupan generasi milenial perlu untuk dikaji berdasarkan prinsip kekristenan, karena sejatinya Zodiak tidak

6 Yuda Permana and Agfianto Eko Putra, “Aplikasi Astrologi (Zodiak) Pada Perangkat Genggam Dengan Menggunakan Teknologi J2me; Application Astrological( Zodiac) On Handheld Device Using J2me Technology" (Universita Gadjah Mada, 2010).

${ }^{7}$ Lina Cahyowati and Estiarto Wahyu Sumirat, "Aplikasi Ramalan Bintang Berbasis Multimedia," Speed-Sentra Penelitian Engineering dan Edukasi 2, no. 1 (2012).

${ }^{8}$ S.S. Wira Kurniawati, "Wacana Ramalan Zodiak Dalam Media Cetak Berbahasa Indonesia" (Universita Gadjah Mada, 2017).

${ }_{9}^{9}$ Arie Afriadi and Dendi Pratama, "Simbol Zodiak Pada Motif Ornamen Kumudawati Pura Mangkunenagaran,” Visual Heritage: Jurnal Kreasi Seni dan Budaya 1, no. 03 (2019): 174-179.

10 Megawati Hadi Wibowo, A. J. Soehardjo, and S.Sn Budi Prasetyadi, "Perancangan Buku Ilustrasi 12 Zodiak Dan Karakteristiknya Untuk Remaja Putri Usia 12-17 Tahun," Jurnal DKV Adiwarna 1, no. 2 (2013): 11.

11 Alister E. Mc. Grath, Apologetika Dasar : Bagaimana Menolong Para Pencari Kebenaran Dan Orang-Orang Skeptis Untuk Percaya Pada Iman Kristen (Malang: Gandum Mas, 2017).

12 Soleman Kawangmani, "Pola Apologetika Kontekstual Untuk Memberitakan Kabar Baik Kepada Suku Jawa Wong Cilik," Gamaliel : Teologi praktika 1, no. 2 (2019): 278-279.

13 Timotius Haryono and Daniel Fajar Panuntun, "Model Apologetika Kreatif-Klarifikasi Dalam Mengomunikasikan Kristus Kepada Remaja Usia Pertengahan (15-18 Th) Melalui Media Youtube," Jurnal Penelitian Sekolah Tinggi Teologi Gamaliel 6, no. 1 (2018).

${ }^{14}$ Daniel Fajar Panuntun, "Misi Apologetika Kristen Online Di Era Diruspsi," Apostolos 2, no. 1 (2019).

15 daniel Fajar Panuntun, "The Social Media Phenomenon Of Satire Account @Gerejapalsu In The Movement Of Holistic Pneumatology In Mission," Jurnal Gamaliel : Teologi Praktika 2, no. 1 (2020). 
terpisahkan dari Gnostisisme yang sudah sudah ada sejak kekristenan mula-mula dan telah dikategorikan oleh bapak-bapak gereja sebagai aliran sesat ${ }^{16}$. Pemahaman terhadap pola apologetika Paulus dalam surat Kolose dapat diaplikasikan untuk mengoreksi generasi milenial Kristen yang terpapar Zodiak sehingga pertumbuhan rohaninya tidak terhambat.

Tulisan ini berfokus pada kajian apologetika secara biblika untuk ditemukan relevansinya bagi permasalahan generasi milinial yang gemar dengan zodiak. Rumusan masalah dari penelitian ini adalah bagaimana aplikasi apologetika rasul Paulus terhadap isu Gnostisisme di jemaat Kolose dalam konteks generasi milenial Kristen yang terpapar Zodiak? Tujuan penelitian yaitu menemukan suatu pola penerapan apologetika rasul Paulus terhadap isi Gnostisisme di jemaat Kolose dalam konteks generasi milenial yang terpapar Zodiak online. Manfaat dari penelitian ini pertama, secara teoritis, penelitian ini yaitu memperkaya ilmu kajian apologetika kontekstual khususnya bagi konteks generasi milenial. Kedua, manfaat praktis, yaitu memberikan sumbangsih pemikiran praktis bagi para pelayanan Kristus khususnya pembimbing rohani pemuda dan remaja dalam memberikan pendampinan yang alkitabiah kepada mereka.

\section{Metode Penelitian}

Penelitian ini menggunakan pendekatan kualitatif dengan jenis penelitian teologis ${ }^{17}$ dan deskriptif sosiall ${ }^{18}$. Penelitian teologis berupa studi eksegesis teks apologetika Paulus terhadap isu gnostisisme di Jemaat Kolose. Penelitian deskriptif sosial adalah mencoba merelevansikan apologetika tersebut sehingga dapat mengatasi fenomena sosial yang muncul di kalangan generasi milineal yang gemar mengkosumsi zodiak. Teknik pengumpulan data melalui studi literature. Selain itu dilakukan wawancara kepada para partisipan dari generasi milenial Kristen (Tery, Angger, Willy) yang terpapar Zodiak. Wawancara juga dilakukan kepada rohaniawan yang pernah melayani generasi milenial yang terpapar Zodiak yaitu Pdm. Mangido Sitompul (GSJA Klaten), Pdt. David Eko Setiawan (GBIS Karanganyar) dan Pdt. Jonedy Ginting (GEKARI Solo). Wawancara dilakukan secara in-depth untuk mendapatkan kedalaman data yang diperoleh dengan peneliti sebagai instrumen untuk memberi-kan expert judgment dari data-data yang telah di peroleh. Proses pengumpulan data dilakukan dengan, pertama, mengumpulkan data-data terkait apologetika Paulus terhadap isu Gnotisisme di jemaat kolose. Kedua, mengumpulkan data-data terkait generasi milenial yang terpapar zodiak. Ketiga, melakukan analisis secara interaktif untuk dapat menemukan relevansi

16 M. Purwatma, “Tantangan Gnostik Bagi Hidup Beriman Masa Kini," Orientasi Baru 21, no. 2 (2012): 189.

17 Stevri Indra Danik Astuti Lumintang Lumintang, Theologia Penelitian Dan Penelitian Theologis Science-Ascience Serta Metodologinya (Jakarta: Geneva Insani Indonesia, 2016).

${ }^{18}$ Kusnaka Adimihardja, Metode Penelitian Sosial : Suatu Teknik Penelitian Bidang Kesejahteraan Sosial Dan Ilmu Sosial Lainnya, ed. Jan Budhi, Edisi ke-8. (Bandung: PT Remaja Rosdakarya Offset, 2011). 
apologetika Paulus terhadap isu Gnotisisme di jemaat Kolose untuk direlevansikan sebagai apologetika kepada generasi milenial yang terpapar zodiak.

\section{Hasil Dan Pembahasan}

\section{Apologetika Paulus Terhadap Isu Gnostisisme dalam Jemaat Kolose Pengantar Surat Kolose}

Kota Kolose terletak di propinsi Romawi wilayah Frigia, Asia kecil (Kisah Para Rasul 18:23). Injil masuk ke kota Kolose ketika Paulus berada di Efesus (Kisah Para Rasul 19:10) dan diduga dibawa oleh Epafras yang mungkin bertobat melalui pelayanan Paulus (Kol 1:7, 4:12-13). Letak kota Kolose sangat terbuka dan srategis bagi perdagangan di bagian timur Kekaisaran Romawi sehingga membuat kota ini mudah dimasuki oleh filsafat-filsafat asing termasuk paham Gnostik. Surat ini ditulis oleh rasul Paulus sekitar tahun $60(1: 1,23,4: 8)$. Paulus menulis surat ini ketika dirinya dipenjara di kota Roma ${ }^{19}$.

\section{Gnostisisme Sebagai Konteks Apologetika Paulus}

Jemaat Kolose adalah jemaat yang menerima Injil dengan iman dan kesungguhan sehingga Injil itu berkembang di seluruh dunia (1:3-6). Namun di tengah kemajuan iman, ada ajaran sesat yang menyelusup masuk dan hendak merusak iman jemaat agar tidak menjadi dewasa di dalam Kristus (2:6-7). Paulus mengingatkan jemaat Kolose demikian, "Hati-hatilah, supaya jangan ada yang menawan kamu dengan filsafatnya yang kosong dan palsu menurut ajaran turun-temurun dan roh-roh dunia, tetapi tidak menurut Kristus" (2:8). Sejatinya dalam jemaat yang didominasi oleh orang non-Yahudi ini berkembang ajaran sesat Gnostik (Gnostisisme). Ajaran ini juga meminjam dan berbaur dengan Yudaisme ${ }^{20}$.

\section{Inti Gnostisisme}

Gnostik (Yunani gnosis, pengetahuan) sudah ada pada 2 abad sM dan merupa-kan ajaran sesat yang tegas ditolak oleh gereja. ${ }^{21}$ Gnostik yaitu percaya adanya dua dunia. Pertama, dunia roh yang murni dan suci sebagai tempat Allah berada. Kedua, dunia materi yang bersifat jahat dan buruk sebagai tempat manusia berada. ${ }^{22}$ Gnostik menolak Allah yang adalah roh sebagai pencipta alam semesta. Bila Allah itu roh, maka Ia baik dan tidak mungkin mau bekerja dengan materi yang jahat. Pencipta adalah serangkaian pancaran (emanasi) Allah yang kurang mengenal Allah bahkan memusuhi Allah yang

${ }^{19}$ J. D. Douglas, Ensiklopedi Alkitab Masa Kini Jilid I (Jakarta: Yayasan Komunikasi Bina Kasih/OMF, 2003), 570; Doreen Widjana, Surat Kolose, 3rd ed. (Bandung: LLB, 1999), 5.

20 J. D. Douglas, Ensiklopedi Alkitab Masa Kini Jilid I, 344; William Barclay, Pemahaan Alkitab Setiap Hari Surat Filipi, Kolose, I \& 2 Tesalonika (Jakarta: BPK Gunung Mulia, 1999), 51.

21 J. D. Douglas, Ensiklopedi Alkitab Masa Kini Jilid I, 343.

22 John Drane, Memahami Perjanjian Baru (Jakarta: BPK Gunung Mulia, 1996), 28. 
sejati. Bagi Gnostik, alam semesta tidak diciptakan dari yang tidak ada melainkan dari materi yang cacat. Gnostik juga tidak mengakui kemanusiaan Yesus. Karena materi itu jahat maka bila Yesus itu anak Allah, Ia tidak mungkin memiliki tubuh yang terdiri dari daging. Kemanusiaan Yesus itu semu (maya), sehingga Ia tidak mungkin menjadi Juruselamat. Oleh karena materi pada dasarnya jahat maka manusia harus mempraktikan hidup bertarak (asketisisme) melalui ketataan penuh terhadap setiap hukum dan larangan serta menolak setiap keinginan. Sifat intelektual dari Gnostik mengharuskan manusia memiliki penge-tahuan rahasia dan sandi-sandi misterius demi mencapai Allah. Sifat sinkritisme dari Gnostik yang menekankan pentingnya memiliki pengetahuan rahasia dan ketataan pada aneka peraturan dalam menjalani diakomodir dalam Yudaisme yang memang syarat dengan hukum Taurat dan ritualiasme yang ketat $^{23}$.

Ciri-ciri ajaran Gnostik nyata di dalam jemaat Kolose. Gnostisisme menyerang ajaran tentang sifat yang secara menyeluruh memadai (total adequacy) dan keunggulan serta keunikan Kristus $(1: 15,19,2: 2,9)$, peranan Kristus dalam penciptaan $(1: 16,17)$, dan karya Kristus dalam penebusan (1:22, 2:9). Bidat ini juga mengajarkan tentang penyembahan kepada malaikat (2:18), memperkenalkan filsafat dan penipuan yang kosong (2:8), pentingnya ritualisme pada hari-hari khusus, (2:16), anjuran bertarak (asketisisme) (2:21) dan unsur astrologi yaitu berjalan menurut roh-roh berbagai unsur dunia (Yunani: stoikheia) terutama bintang-bintang dan planet-planet $(2: 8,20)$. Astrologi diyakini dapat melengkapi manusia dengan pengetahuan rahasia yang sanggup melepaskannya dari perbudakan roh-roh tersebut. Sejatinya guru-guru palsu mengajarkan paham Gnostik untuk mengalihkan kekristenan menjadi suatu filsafat dan teosofi dan meruntuhkan iman Kristen ${ }^{24}$.

\section{Pola Apologetika Klarifikatif Rasul Paulus}

Paulus dalam surat ini menggunakan kata 'kita' sebanyak 8 kali $(1: 1,13,14$, $2: 6,13,14,4: 7,9)$, sebagai upaya untuk menciptakan area pijakan bersama dalam berkomunikasi (common ground) dengan jemaat Kolose. Sesungguhnya Paulus, Timotius dan jemaat Kolose sebagai sesama orang percaya kepada Yesus Kristus dan Injil. Common ground bagi Paulus agar ketika ia memberi peringatan, mengoreksi, melarang dan memerintahkan hal-hal yang harus dilakukan oleh jemaat Kolose, mereka tidak menolaknya. Sebaliknya menanggapinya secara positif.

Paulus juga menyadari bahwa guru-guru palsu hendak menanamkan perspektif kepada jemaat Kolose bahwa beriman kepada Kristus belum cukup memadai untuk mencapai Allah demi memperoleh kemuliaan. Karena Kristus hanyalah salah satu dari berbagai manifestasi Allah. Dan karena itu diperlukan tambahan hikmat Gnostik yang

\footnotetext{
23 Barclay, Pemahaan Alkitab Setiap Hari Surat Filipi, Kolose, I \& 2 Tesalonika, 151-153.

24 Ibid., 146-154.
} 
menggabungkan spekulasi-spekulasi filosofis dan legalisme/ritualisme agar dapat datang kepada Allah. Karena itu sepajang pasal 1:1-4:5, Paulus berupaya memberikan pertanggungjawaban iman dalam Kristus dan Injil melalui suatu pola apologetika yang bersifat penjelasan (klarifikasi) berkenaan dengan keutamaan dan keunggulan Yesus Kristus di dalam dan di atas segala sesuatu (1:15-19, 2:3, 15, 3:1-4, 11). Sehingga Gnostisisme itu ditolak jemaat berbasis pemahaman secara asasi tentang keutamaan dan keunggulan Kristus itu.

Isi apologetika Paulus dalam Kolose 1:1-4:5 sebagai berikut: Pertama, Pengalaman rohani sejati tentang keutamaan Kristus dalam Injil (1:1-8). Bagi Paulus jemaat Kolose adalah saudara dan orang-orang kudus. Status orang kudus dimiliki karena jemaat telah mendengar Injil dan beriman kepada Kristus sebagai berita utama dari Injil. Paulus bersyukur bahwa pengalaman rohani jemaat tentang keutamaan Kristus dalam Injil ternyata tidak sia-sia. Sebaliknya jemaat tetap hidup di dalam iman, kasih dan pengharapan. Bahkan Injil itu berbuah dan berkembang dan menjadi kesaksian yang hidup bagi banyak orang. Paulus menjelaskan bahwa semua ini terjadi hanya oleh karena orang Kolose sudah berjumpa secara personal (personal encounter) dengan Yesus Kristus yang adalah wujud nyata kasih karunia Allah kepada mereka sebagai manusia berdosa.

Kedua, Pengembangan pengalaman rohani sejati tentang keutamaan Kristus dalam Injil (1:9-12). Rentang ayat 9-12 berpangkal pada doa Paulus agar jemaat terus bertumbuh dalam segala hikmat ilahi untuk mengetahui kehendak Tuhan dengan sempurna. Paulus mau agar jemaat memperbesar kapasitas pengalaman rohani di dalam Kristus sehingga berkenan kepada Allah di dalam segala aspek kehidupan.

Ketiga, Keutamaan dan keunikan Kristus dalam Penebusan (1:13-14). Dunia dan segala isinya termasuk manusia adalah ciptaan Allah. Allah yang adalah Roh dan Mahasuci menciptaan dari tidak ada menjadi ada. Dunia dan manusia ciptaan Allah itu baik adanya. Tetapi kejatuhan manusia dalam dosa membuat manusia berada di dalam kuasa kegelapan yang membawa kepada kebinasaan. Oleh karena itu pengalaman iman jemaat Kolose terjadi bukan karena religiusitasnya, tetapi karena tindakan penebusan Kristus. Dengan jalan penebusan, Allah telah memindahkan jemaat Kolose dan Paulus ke dalam kerajaan Anak-Nya yang kekasih. Allah berkenan atas penebusan Kristus karena hanya Kristuslah hanya memenuhi syarat untuk menjadi Juruselamat. Yesus Kristus adalah manusia sejati yang hidup tanpa dosa sehingga Ia layak mewakili manusia untuk dihukum mati di kayu salib. Ia juga Allah sejati sehinggga Ia bangkit dari kematian untuk menyediakan pengampunan dosa dan kehidupan kekal di dalam Kerajaan-Nya yang terkasih. Inilah keunikan dan keutamaan Kristus yang sangat jelas dalam karya penebusan. 
Keempat, Keutamaan dan kemahakusaan Kristus dalam penciptaan (1:15-17). Paulus kemudian menjelaskan bahwa di dalam Kristus, Allah yang adalah Roh adanya itu menjadi nyata bagi dunia. Hal ini berarti Yesus Kristus yang adalah Allah Manusia sejati itu sudah ada sejak kekekalan. Keilahian Yesus merupakan inti dari iman Kristen. Kekristenan dengan tegas mengakui bahwa Yesus disebut sebagai 'manusia sejati' dan sekaligus 'Allah sejati'. ${ }^{25}$ Dalam kekekalan ke-Allah-an-Nya itu, Ia terlibat dalam penciptaan dengan kemahakuasaan-Nya. Kristus menjadi asal-muasal dan pangkal segala sesuatu baik di sorga maupun di bumi. Di dalam Dia, yang tidak ada menjadi ada, dan baik adanya. Dan Kristus pula yang menjadi tujuan akhir segala sesuatu. Sehingga Dia menjadi yang terutama di atas segala ciptaan.

Kelima, Keutamaan dan keagungan Kristus dalam jemaat (1:18-23). Prakarsa Allah untuk mendamaikan manusia berdosa dengan diri-Nya melalui keagungan salib Kristus dan kebangkitan-Nya, mendudukkan jemaat itu kudus dan tak bercacat di hadapan-Nya. Itulah sebabnya bahwa keutamaan Kristus dalam karya pendamaian membuat-Nya layak menjadi Kepala tubuh yaitu jemaat. Penjelasan ini menjadi dasari nasehat Paulus agar jemaat berkomitmen total pada Injil.

Keenam, Keutamaan dan kewibawaan Kristus dalam pelayanan (1:24-29, 2:1-5). Paulus menjelaskan bahwa ia bersukacita karena ia boleh menderita bagi jemaat dan terus berjuang agar jemaat semakin mengenal keutamaan Kristus serta menuntun mereka kepada kesempurnaan di dalam Kristus. Bagi Paulus pelayanan-nya adalah tugas dari Allah untuk memberitakan Kristus yang memang menjadi misteri bagi bangsa-bangsa lain tetapi dinyatakan kepada orang-orang kudus-Nya. Penjelasan ini diharapkan menyadarkan jemaat akan pengorbanannya demi pengenalan mereka sendiri akan Kristus. Dan karena itu jangan mau diperdaya oleh guru-guru palsu. Sebaliknya memiliki tertib hidup dan keteguhan iman di dalam Kristus.

Ketujuh, Keunggulan Kristus atas astrologi (2:6-10). Paulus mengingatkan jemaat bahwa mereka sudah menerima Kristus yang terutama dan unggul atas segala sesuatu. Karena itu mereka harus tetap di dalam Dia, bertumbuh di dalam Dia, dibangun di atas Dia, dan bertambah teguh dalam iman dan hati mereka melimpah dengan syukur. Tanpa bertumbuh menuju kedewasaan di dalam Kristus mereka akan mudah dipikat oleh ajaran asing. Dan sebagaimana dikemukakan di depan bahwa jemaat Kolose sedang terpapar roh-roh berbagai unsur dunia (Yunani stoikheia) terutama bintangbintang dan planet-planet (astrologi) yang dipercayai akan mengarahkan masa depan dan membebaskannya dari roh yang mencelakakan $(2: 8,20)$. Paulus menjelaskan bahwa di dalam Kristus berdiam secara jasmaniah seluruh kepenuhan ke-Allahan, dan jemaat Kolose sudah dipenuhi di dalam Dia. Kristus adalah kepala semua penguasa termasuk

\footnotetext{
${ }^{25}$ Kalis Stevanus,"Bukti Keilahian Yesus Menurut Injil" Jurnal Teruna Bhakti, Volume 2, No 2, Pebruari 2020:282.
} 
terhadap roh-roh yang embahayakan. Astrologi dan ramalan Zodiak tidak layak diandalkan masa depan esok, karena memang hanyalah rekaan manusia semata. Kristus sang Penguasa itu unggul atas Astrologi dan roh-roh duniawi.

Kedelapan, Keunggulan Sunat Kristus atas Hukum Sunat manusia (Ritualisme) (2:11-17). Paulus menjelaskan juga bahwa sinkritisme Gnostik dan Yudaisme yang mempromosikan hukum sunat (legalisme) sebagai unsur penyempurna iman kepada Kristus sesungguhnya tidak memiliki kuasa apapun. Karena sunat manusia sebagaimana digariskan hukum taurat tidak dapat menanggalkan tubuh dosa. Tetapi sunat Kristus yang membebaskan dari tubuh dan hutang dosa untuk memperoleh hidup yang kekal. Jadi iKristus unggul atas legalisme. Oleh karena itu jemaat Kolose harus menolak secara tegas hukum sunat lahiriah.

Kesembilan, Keunggulan Kristus atas Legalisme, Mistisisme dan Asketisisme (2:18-23). Ada tiga peringatan Paulus. Pertama, “...Janganlah kamu biarkan orang menghukum kamu" (ayat 16-17). Karena jemaat sudah dimerdekakan dari dosa oleh Kristus, maka segala peraturan tentang makanan, minuman dan penanggalan (Legalisme Yahudi) sesungguhnya tidak mendatangkan manfaat rohani apapun. Karena semuanya hanya bayangan sedang penggenapannya adalah Kristus. Artinya Kristus unggul atas Legalisme. Dan jemaat harus menolak untuk kembali pada sesuatu yang bersifat bayangan. Kedua, "Janganlah kamu biarkan kemenanganmu digagalkan oleh orang...(ayat 18-19). Pengalaman mistik secara langsung dengan malaikat-malaikat dan pengalaman misteri penglihatan terhadap dimensi roh di luar Kristus dan Roh Kudus hanya menghasilkan kerendahan hati semu dan spiritualitas yang kosong. Karena memang mistisisme tidak memiliki kuasa transformative atas batin serta karakter manusia berdosa. Sebaliknya dengan menjadikan Kristus kepala dan jemaat itu tubuhNya akan mendatangkan pertumbuhan ilahi dalam seluruh aspek hidupnya. Jadi Kristus yang adalah kepala tubuh yaitu jemaat unggul atas mistisisme. Kejelasan pemahaman akan Kristus sebagai kepala tubuh seharusnya membuat jemaat Kolose menolak mistisisme. Ketiga, "...kamu telah mati bersama-sama Kristus dan bebas dari roh-roh dunia, mengapakah kamu menaklukan dirimu pada peraturan-peraturan seolah-olah kamu masih hidup di dunia..."(ayat 20-23). Paulus menjelaskan bahwa status jemaat Kolose yaitu sudah bangkit bersama Kristus. dan menjadi warga kerajaan sorga. Karena itu sekalipun masih berada di dunia, pola hidupnya tidak boleh mengikuti pranata dunia termasuk meningkatkan kualitas rohani dengan Asketisisme. Asketisisme sesungguhnya adalah ritual buatan manusia untuk memuaskan hidup duniawi (antroposentrisme). Kristus unggul atas Asketisisme. Dan jemaat sudah memiliki pola hidup ilahi itu karena statusnya sebagai warga Kerajaan sorga. Jemaat harus tegas menolak praktik Asketisisme. 
Kesadaran jemaat akan segala kelimpahan anuegrah di dalam Kristus mesti dipertanggugngjawabkan dalam seluruh aspek kehidupannya, sebagaimana dipapar-kan berikut ini.

Kesepuluh, Pertanggungjawaban hidup Kristen berbasis keutamaan dan keunggulan Kristus dalam aspek personal holiness (3:1-4). Pertanggungjawaban hidup Kristen yang sejati adalah hidup sesuai dengan jati dirinya sebagai milik Kristus yaitu fokus kepada Kristus saja. Karena memang hidup jemaat sudah tersembunyi bersama Kristus di dalam Allah. Paulus menesehati orang-orang Kolose agar 'carilah' dan 'pikirkanlah' perkara yang di atas dimana Kristus ada. Hanya dengan jalan itu, maka sudut pandang (point of view) orang percaya tetap terjaga yaitu Kristosentris di tengah pergulatan dan tawaran aneka faham filsafat dunia dan sebagainya. Inilah kekuatan personal holiness yang membebaskan orang percaya dari keduniawian. Karena yang bersumber dari dunia tidak layak dibandingkan dan ditandingkan dengan keutamaan dan keunggulan Kristus. Yang datang dari Allah itu kekal dan mulia sedang yang dari berasal dunia itu fana dan cacat. Praksis hidup 'carilah dan pikirkanlah perkara yang di atas' yaitu melalui kualitas disiplin rohani untuk belajar mengenal Dia melalui FirmanNya, berdoa dan bersekutu dengan sesama orang percaya secara terus-menerus. Semua ini akan mendatangkan kemuliaan bagi setiap orang percaya bersama Kristus yang mulia kelak.

Kesebelas, Pertanggungjawaban hidup Kristen berbasis keutamaan dan keunggulan Kristus dalam aspek Transformasi karakter ilahi (3:5-17). Kedekatan itu keserupaan (Closeness is likeness). Hidup rohani yang berfokus dan terfokus pada Kristus tidak hanya menghasilkan status orang kudus tetapi juga pembaruan (transformasi) karakter secara terus-menerus untuk menjadi seperti karakter Kristus. Perubahan karakter akan berdampak pada cara memperlakukan sesama orang percaya sebagai satu saudara dalam Kristus baik dalam mengampuni, mengasihi dan lainnya tanpa bersikap memilah dan memilih berdasarkan suku, ras dan lainnya. Dan akan memuncak pada ketaatan untuk memberlakukan seluruh kehendak Kristus sambil mengucap syukur oleh Dia kepada Allah Bapa. Semua hal ini tidak akan dicapai melalui astrologi, ritualisme dan askestisme. Astrologi, ritualisme dan asketisme hanya sebatas memperbaiki karakter tetapi hanya Kristuslah yang memperbarui karakter karena kuasa keilahian-Nya.

Keduabelas, Pertanggungjawaban hidup Kristen berbasis keutamaan dan keunggulan Kristus dalam aspek keluarga (3:18-21). Paulus Paulus memperluas penjelasan tentang pertanggungjawaban hidup ke praksis hidup berkeluarga. Pola relasi istri dan suami Kristen berbeda dengan yang lain. Isteri tunduk kepada suaminya sebagaimana seharusnya di dalam Tuhan. Suami mengasihi isterinya berdasarkan teladan kasih Kristus dan tidak menjadi pemicu terjadinya kekerasan dalam rumah tangga (KDRT). Tentu untuk menjadi model kelurga teladan bagi dunia, kriteria calon 
pasangan haruslah yang sudah mengalami personal encounter dengan Kristus. Proses menemukan calon pasangan (jodoh) juga harus sesuai kehendak Kristus, bukan mencari berdasarkan rujukan astrologi (ramalan zodiak) atau tatanan kecocokan berpasangan berdasarkan hari-hari kelahiran sebagaimana ajaran leluhur (Jawa. weton). Satu kesatuan praksis mempersiapkan pernikahan dan menjalani hidup berkeluarga berbasis keutamaan dan keunggulan Kristus merupakan model pertanggungjawaban keluarga Kristen kepada dunia.

Ketigabelas, Pertanggungjawaban hidup Kristen berbasis keutamaan dan keunggulan Kristus dalam aspek Profesi (3:22-4:1). Dimensi pertanggungjawaban hidup Kristen mencakup juga profesi. Entah kedudukan sebagai hamba (bawahan) atau tuan (majikan atau pimpinan) harus berdasarkan kehendak Kristus dan untuk Kristus sebagai sumber upah dan berkat serta sang Hakim yang adil yang menghakimi semua orang kelak. Kristus sudah mati dan bangkit serta memperbarui hidup kaum profesional Kristen. Oleh karena itu motif, cara serta tujuan bekerja dari kaum profesional Kristen haruslah Kristosentris. Bukan rujukan pada ramalan Zodiak dan spekulasi peruntungan atau kerugian bekerja lainnya.

Keempatbelas, Pertanggungjawaban hidup Kristen berbasis keutamaan dan keunggulan Kristus dalam aspek persekutuan dan kesaksian orang percaya (4:2-4). Pertanggungjawaban hidup Kristen yang tidak terpisahkan dari panggilan Allah ke dalam yaitu untuk beribadah, bersekutu dan bertumbuh dalam pengajaran Firman Allah. Dan panggilan pengutusan kepada dunia untuk memberitakan Injil, bersaksi dan melakukan pelayanan kasih. Ketekunan berdoa dan berjaga-jaga sambil mengucap syukur merupakan kekuatan ilahi yang menghasilkan terobosan-terobosan demi keberhasilan pelayanan. Bukan pengalaman mistik, ritualisme, asketisme atau lainnya dari para pelayan yang memberi wibawa kepada hidup rohani dan pelayanan. Ketekunan berdoa dan ucapakan syukur jemaat merupakan penopang bagi pelayanan para pelayan Kristus yang menjamin kemenangan dalam perjumaan dengan kuasakuasa dunia (power encounter). Dan akan mencerahkan manusia berdosa untuk terbuka kepada kebenaran Injil (trurth encounter) tentang keutamaan dan keunggulan Kristus yang harus diimani.

Kelimabelas, Pertanggungjawaban hidup Kristen berbasis keutamaan dan keunggulan Kristus dalam konteks global (4:5-6). Kehidupan orang percaya secara utuh adalah pertanggungjawaban Kristen tentang Kristus yang terutama dan unggul itu dihadapan siapa saja di bawah kolong langit ini. Hikmat, dan perkataan Kristus yang memenuhi, menguasai dan memberi isi pada komunikasi dalam pergaulan hidup Kristen sesungguhnya sangat memadai (total adequasy) untuk memberi makna kekal dalam setiap waktu dan kesempatan perjumpaan dengan sesama (social encounter). Sehingga orang lain akan diinsyafkan tentang keutamaan dan keunggulan Kristus. Dan pada 
gilirannya mau meninggalkan gnostisisme dengan segala variasi bidatnya. Selanjutnya mau datang untuk menyembah dan mengakui Kristus sebagai Juruselamat dan Tuhannya sebagai pengalaman rohani sejati yang membawanya kepada kekekalan dan kemuliaan bersama Allah kelak sebagai tujuan akhir setiap manusia.

\section{Generasi Milenial yang Terpapar Zodiak.}

Generasi milenial adalah generasi kelahiran antara tahun 1980 hingga awal tahun 2000. Generasi milenial ini disebut juga dengan generasi Y yang lahir setelah generasi x (babby boomer) 26 . Berbagai istilah popular disematkan pada generasi ini seperti generasi why karena mencerminkan sikak karakter berani, kreatif, inovatif, dan modern. Generasi ini juga sering disebut juga generasi yang terhubung atau connected/digital generation. Generasi ini juga memiliki sikap yang handal dalam bekerja, meneliti, dan memberikan sumbangsih pemikiran yang inovatif. Kekuatan utama generasi ini adalah pada etos kerja kompetitit, terbuka dan fleksibel ${ }^{27}$. Berdasarkan hal tersebut generasi ini merupakan generasi yang aktif dan dapat di jumpai dengan mudah pada era media sosial yang berkembang sangat pesat. Deskripsi klasifikasi generasi millenial dapat dilihat dari tabel berikut:

\begin{tabular}{|c|c|c|c|c|c|}
\hline Sumber & & & Label & & \\
\hline Tapscott (1998) & - & $\begin{array}{c}\text { Baby Boom } \\
\text { Generation } \\
(1946-1964)\end{array}$ & $\begin{array}{l}\text { Generation X } \\
(1965-1975)\end{array}$ & $\begin{array}{c}\text { Digital } \\
\text { Generation } \\
(1976-2000)\end{array}$ & - \\
\hline $\begin{array}{l}\text { Howe \& Strauss } \\
(2000)\end{array}$ & $\begin{array}{c}\text { Silent } \\
\text { Generation } \\
(1925-1943)\end{array}$ & $\begin{array}{c}\text { Boom } \\
\text { Generation } \\
(1943-1960)\end{array}$ & $\begin{array}{l}1^{\text {th }} \text { Generation } \\
(1961-1981)\end{array}$ & $\begin{array}{c}\text { Millenial } \\
\text { Generation } \\
(1982-2000)\end{array}$ & \\
\hline $\begin{array}{l}\text { Zemke et al } \\
(2000)\end{array}$ & $\begin{array}{c}\text { Veterans } \\
(1922-1943)\end{array}$ & $\begin{array}{c}\text { Baby Boomers } \\
(1943-1960)\end{array}$ & $\begin{array}{c}\text { Gen-Xers } \\
(1960-1980)\end{array}$ & $\begin{array}{c}\text { Nexters } \\
(1980-1999)\end{array}$ & \\
\hline $\begin{array}{c}\text { Lancaster \& Stillman } \\
(\mathbf{2 0 0 2 )}\end{array}$ & $\begin{array}{l}\text { Traditionalist } \\
(1900-1945)\end{array}$ & $\begin{array}{c}\text { Baby Boomers } \\
(1946-1964)\end{array}$ & $\begin{array}{c}\text { Generation Xers } \\
(1965-1980)\end{array}$ & $\begin{array}{l}\text { Generation Y } \\
(1981-1999)\end{array}$ & - \\
\hline $\begin{array}{l}\text { Martin \& Tulgan } \\
\quad(2002)\end{array}$ & $\begin{array}{c}\text { Silent } \\
\text { Generation } \\
(1925-1942)\end{array}$ & $\begin{array}{c}\text { Baby Boomers } \\
(1946-1964)\end{array}$ & $\begin{array}{l}\text { Generation X } \\
(1965-1977)\end{array}$ & $\begin{array}{l}\text { Millenials } \\
(1978-2000)\end{array}$ & \\
\hline $\begin{array}{c}\text { Oblinger \& Oblinger } \\
(2005)\end{array}$ & $\begin{array}{l}\text { Matures } \\
(<1946)\end{array}$ & $\begin{array}{c}\text { Baby Boomers } \\
(1947-1964)\end{array}$ & $\begin{array}{c}\text { Generation Xers } \\
(1965-1980)\end{array}$ & $\begin{array}{c}\text { Gen-Y/NetGen } \\
(1981-1995)\end{array}$ & $\begin{array}{r}\text { Post Millenials } \\
(1995 \text {-present }\end{array}$ \\
\hline
\end{tabular}

Tabel 1. Pengelompokan Generasi $X^{28}$

Generasi ini memiliki karakter yang sangat sesuai untuk dapat bertahan di era teknologi informasi yang berkembang sangat cepat. Karakter utama dari generasi ini diantaranya adalah: karakteristik mandiri (berdikari), memiliki perasaan percaya diri, dan mengutamakan orientasi pada hasil. Generasi memiliki kekuatan utama yaitu dapat bekerja dengan berbagai macam penguasaan yang tinggi terhadap teknologi. Hal ini

${ }^{26}$ Dwiyuni Evi Yolanda, Isti Mulayani, and M Januar Ibnu Adham, "Pengaruh Generasi Muda Millenial Terhadap Karakter Interaksi," Journal of Chemical Information and Modeling 53, no. 9 (2013): 1689-1699.

27 Retnayu Prasetyanti and Sisman Prasetyo, “Generasi Millennial Dan Inovasi Jejaring Demokrasi Teman Ahok," Jurnal Polinter 3, no. 1 (2017): 44-52.

28 Yolanda, Mulayani, and Adham, "Pengaruh Generasi Muda Millenial Terhadap Karakter Interaksi." 
yang membuat self esteem (kepercayaan diri mereka dapat meningkat) ${ }^{29}$. Karakteristik yang menjadi keunggulan utama pada generasi ini adalah memiliki potensi kreativitas. Generasi ini memeliki teknik berpikir yang out of the box yaitu menghasilkan ide-ide yang bermanfaat pada institusi/perusahan yang dia tempati ${ }^{30}$. Berdasarkan hal tersebut generasi milenial memiliki karakter dan daya saing yang tinggi di masa kini. Berbagai hal tentang teknologi dan kepercayaan diri mendorong mereka untuk terus ingin tahu dan mengembangkan pemikirannya. Tentunya hal ini akan membawa dampak positif dan dampak negatif bagi perkembangan generasi millenial di Indonesia.

Perkembangan teknologi yang erat kaitannya dengan kehidupanan generasi millenial perlu mendapatkan perhatian khusus. Generasi ini dapat menerima semua informasi dari berbagai teknologi informasi karena generasi ini memiliki daya selancar dan ingin tahu yang tinggi oleh karena kepercayaan dirinya. Berbagai hal negative seperti hoax dan ujaran kebencian dapat meracuni generasi ini ${ }^{31}$. Hal ini tentunya harus diantisipasi karena berbagai pernyebaran informasi tersebut imbas pertamanya adalah pada generasi millenial. Berbagai informasi yang berkembang tersebut memberikan dampak bagi cara pandang hidup generasi millenial, salah satunya adalah mengenai zodiak atau ramalan bintang. Tentunya generasi ini sudah akrab dengan kemudahan teknologi sehingga zodiak atau ramalaman bintang yang cukup digemari oleh para generasi millenial dapat dengan mudah untuk di akses.

Dampak negative dari perkembangan dunia maya akibat pengaruh perkembangan teknologi informasi yang pesat harus ditangani karena berimbas secara langsung pada kehidupan generasi millenial salah satunya adalah mengenai zodiak. Pendidikan karakter dibutuhkan sehingga generasi millenial dapat terhindar dan dapat mengetahui yang baik dan benar ${ }^{32}$. Hal ini tentunya termasuk pendidikan karakter juga diperlukan bagi para generasi milenial yang terpapar dan menggemari zodiak. Masalah zodiak ini dapat merubah cara pandang teologi dari generasi millenial dalam melihat keseluruhan hidup dan imannya pada Tuhan.

Zodiak ini cukup digemari di kalangan remaja terkhusus remaja generasi millenial. Zodiak merupakan pola konsumsi media bagi para generasi millenial. Kebiasaan ini tetap terjaga meskipun kemungkinan sekarang medianya berubah. Apabila dulu zodiak berada pada media-media cetak seperti majalah sekarang berkembang pada media online yang juga dapat diakses dengan mudah oleh generasi millenial. Salah satu media sosial yang dimari adalah ask fm lightgivers. Media ini

${ }^{29}$ Justin Meier and Stephen Austin, “Generation Y in the Workforce: Managerial Challenges," The Journal of Human Resource and Adult Learning 6, no. 1 (2010).

30 Puti Archiantia, "Memprediksi Kreativitas Generasi Millenial Di Tempat Kerja," Jurnal Ilmiah Penelitian Psikologi: Kajian Empiris \& Non-Empiris 3, no. 2 (2017): 61-68.

31 Iffah Al Walidah, “Tabayyun Di Era Generasi Millenial,” Jurnal Living Hadis 2, no. 2 (2018): 317.

32 Kalfaris Lalo, "Menciptakan Generasi Milenial Berkarakter Dengan Pendidikan Karakter Guna Menyongsong Era Globalisasi," IImu Kepolisian 12, no. 2 (2018): 68-75. 
merupakan salah satu akun dari ask fm yang berisi mengenai zodiak atau ramalan bintang, tentunya dinikmati oleh berbagai kalangan generasi millenial ${ }^{33}$.

Ramalan bintang tersebut dapat dijumpai dengan mudah pada berbagai media sosial online. Salah satu ramalan bintang tersebut adalah pada forum ramalan bintang yang disediakan oleh ask fm. Forum ini merupakan forum interaktif untuk sama-sama membahas mengenai ramalan bintang atau horoskop. Uniknya, forum ini menyajikan bentuk ramalan bintang tidak hanya terbatas pada tulisan akan tetapi secara interaktif melalui video. Hal ini tentunya akan sangat digemari dan direspon oleh generasi millenial dan kemudian di cocokan pada kehidupannya masing-masing. Ramalan bintang ini meliputi kehidupannya di bulan tersebut baik

kehidupan, pekerjaan, dan relasi yang merupakan aspek yang sangat digemari oleh generasi millenial untuk di bahas. Tampilan tersebut dapat dilihat seperti gambar di bawah ini.

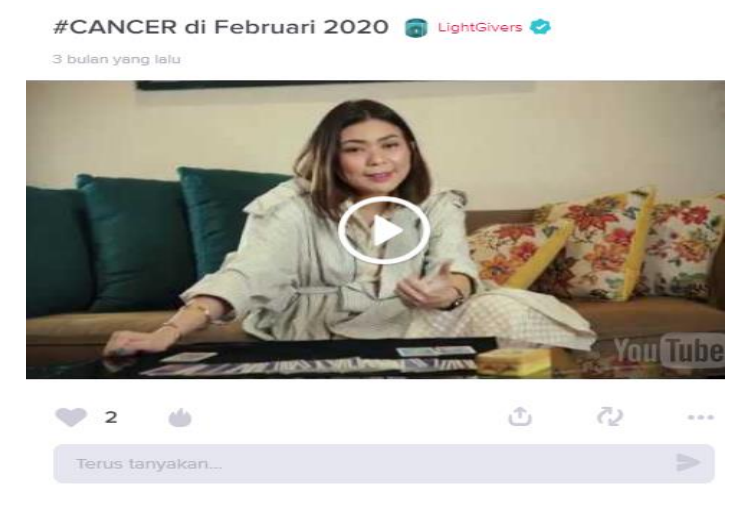

Gambar 1. Tampilan Ramalan Bintang pada ask $\mathrm{fm}^{34}$.

Zodiak pada era media sosial tentunya akan semakin berkembang dan mempengaruhi kehidupan generasi milenial. Menurut penelitian Rosa, bahwa generasi yang menyukai ramalan bintang memiliki tiga tipe pemaknaan terhadap berbagai ramalan tersebut. Tiga tipe pemaknaan tersebut diantaranya adalah: negotiated reading, dominant-hegemonic, dan oppositional reading. Kalangan yang memiliki kepercayaan pada ramalan bintang tersebut hingga memiliki pengharapan pada ramalan bintang tersebut masuk pada dominant-hegemonic. Kalangan yang masih mempertimbangakan hal mengenai isi zodiak kemudian menyesuaikan dengan keadaan dirinya hingga sampai berdampak pada perubahan sikap termasuk pada

33 Teofani Dela Rosa, “Analisis Resepsi Pembaca Ramalan Zodiak Di Ask FM Lightgivers” (Universitas Diponegoro Semarang, 2016).

${ }^{34}$ LightGivers, “\#CANCER Di Februari 2020," Askfm, last modified 2020, accessed April 27, 2020, https://ask.fm/LightGivers. 
kalangan negotiated reading. Kalangan yang tidak percaya sama sekali termasuk pada kalangan oppositional reading ${ }^{35}$. Tiga sikap tersebut yang berkaitan pada pola kepercayaan generasi millenial terhadap ramalan bintang atau zodiak. Hal ini yang menjadi fokus pemikiran bagaimana bentuk apologetika Kristen dalam menyikapi pandangan hidup generasi milenial sekarang terhadap ramalan bintang/ zodiak.

\section{Deskripsi Data Wawancara}

Deskripsi data hasil wawancara kepada partisipan dari generasi milenial dan para hamba Tuhan yang melayani para pecinta zodiak dipaparkan berikut ini.

\section{Alasan dan Tujuan Membaca Ramalan Zodiak}

Ada berbagai alasan Generasi milenial tertarik membaca ramalan Zodiak yaitu: 1) sekedar mengikuti teman; 2) iseng atau sekedar mencoba; 3) karena Zodiak memberi pengaruh dan petunjuk hidup; ${ }^{36}$ karena terlalu percaya takhayul; 4) karena sesuatu yang telah ditanamkan dalam dirinya; 5) pelarian dari kekosongan hidup dan mencari hiburan; 6) merasa dirinya menjadi lebih cocok dengan tanda Zodiak tertentu; 7) dan mampu membina relasi yang lebih serasi dengan tanda bintang tertentu.

Umumnya generasi milenial membaca Zodiak dengan tujuan yaitu untuk mengetahui nasib dan kepribadiannya, menghindari kesialan dan kecelakaan, mencari kesenangan dan peruntungan, mendapatkan peringatan, rasa aman, bimbingan dan arah serta makna hidup, dan lebih percaya diri dalam membuat keputusan untuk menjalani kehidupan.

\section{Dampak Membaca Ramalan Zodiak Terhadap Kerohanian}

Ada partisipan yang mengatakan bahwa ia menganggap ramalan Zodiak itu benar dan beberapa kali mengalami hal-hal sebagaimana isi ramalan Zodiak itu. Para partisipan juga mengatakan bahwa mereka tidak menyadari bahwa praktik membaca Zodiak adalah ocultisme dan berdosa kepada Allah. Ada pecinta zodiak yang dilayani para hamba Tuhan yang kemudian mengalami kecanduan atau terikat dengan ramalan Zodiak dimana bila ia tidak membacanya maka akan muncul ketakutan dalam dirinya. Demikian pula ada pecinta zodiak yang pada awalnya sekedar membaca ramalan Zodiak, namun kemudian melakukan ocultisme lainnya dan spiritisme. Berdasarkan fakta-fakta ini nyata bahwa membaca ramalan Zodiak adalah dosa yang akibat rohani yang serius.

\section{Dinamika Pelayanan Kepada Generasi Milenial yang Terpapar Ramalan Zodiak}

35 Rosa, “Analisis Resepsi Pembaca Ramalan Zodiak Di Ask FM Lightgivers.”

36Wawancara dengan Partisipan 
Generasi milenial yang terpapar ramalan Zodiak berhenti dari praktik Zodiak karena:

1. Didikan Orangtua

Orangtua ketika mengetahui anaknya membaca ramalan Zodiak memberikan pengajaran, nasehat dan peringatan bahwa orang Kristen tidak boleh percaya kepada ramalan-ramalan Zodiak. Dan hasilnya anak-anak mereka berhenti dari Zodiak.

2. Bimbingan Rohani Secara Pibadi oleh Hamba Tuhan

Pelayanan kepada para pecinta Zodiak yaitu, pertama, Membangun Relasi. Para pelayan dapat melayani para pecinta Zodiak karena ada kedekatan relasi dengan mereka. Melalui proses pendekatan yang intens, mereka dapat terbuka kepada para hamba Tuhan untuk menceritakan latar belakang ketertarikan mereka kepada ramalan Zodiak.

Kedua, Menelusuri Latar Belakang Keluarga dan Pertemanan. Fakta-fakta menunjuk-kan bahwa ada banyak faktor yang membuat generasi milenial tertarik untuk membaca ramalan Zodiak. Ada yang membaca zodiak karena kurangnya perhatian dari orangtua oleh karena orangtuanya bercerai. Mereka mencari cara mengisi kekosongan hidup dari Zodiak. Adapula karena keteladanan yang buruk dari orangtua atau keluarga dekat yang melakukan praktik ocultisme sekalipun beragama Kristen sehingga merekapun terlibat di dalamnya.

Ada yang terikat dengan Zodiak karena pertemanan yang buruk. Berawal dari mengikuti ajakan teman melihat berbagai tulisan Zodiak maupun video praktik ocultisme di Internet akhirnya mereka melakukan sendiri bahkan kemudian terikat dengan aneka praktik ocultimse dan spiritisme. Hal mana mengisyaratkan bahwa menolong generasi milenial tidak hanya agar mereka berhenti melakukan praktif Zodiak tetapi untuk pelayanan agar terbebas dari okultisme dan spiritisme yang lebih menyeluruh.

Ketiga, Penjelasan Firman Allah dan Pertobatan. Pelayanan kepada generasi milenial diawali dengan memberikan penjelasan bahwa praktik ramalan Zodiak adalah dosa. Dasar Firman Allah yang dijelaskan yaitu Imamat 19:26 yang berkata, "Janganlah kamu melakukan telaah atau ramalan." Praktik ramalan Zodiak juga terkai erat dengan praktik jampi yang dilakukan oleh anak-anak Skewa (Kisah Para Rasul 19:13-20). Dan orang-orang yang terlibat di dalamnya tidak memperoleh bagian di dalam kerajaan Sorga (Wahyu 20:15). Semua praktik ini adalah perbuatan gelap (Okultisme). Sebaliknya hidup anak-anak Allah dituntun oleh Tuhan sebagaimana Firman-Nya dalam Amsal 20:24 yang berkata demikian, "Langkah orang ditentukan Tuhan...". Oleh karena itu perlu langkah pertobatan dan tekad untuk meninggalkan semuanya. Setelah langkah penjelasan di atas, mereka dibimbing untuk mengakui di hadapan Allah sebagai orang berdosa. 
Keempat, Motivasi untuk Belajar Firman, Beribadah dan Melayani. Anak-anak yang telah bertobat dan meninggalkan praktik zodiac dimotivasi untuk bertumbuh dalam Firman Allah, setia beribadah dan melayani Tuhan. Mereka dimotivasi untuk mempelajari Injil Yohanes untuk mengenal Yesus Kristus dan Surat I Yohanes untuk memperoleh keteguhan identitas dirinya sebagai anak-anak Allah dan menghayati kasih Allah akan dirinya.

Hasil-hasil pelayanan dari para hamba Tuhan yaitu anak-anak yang dilayani itu bertobat dan beriman kepada Yesus Kristus sebagai Tuhan dan Juruselamatnya. Mereka kemudian tidak percaya dan berhenti dari membaca ramalan Zodiak. Ada yang bergabung dalam kelompok pemuridan (Komsel) di gereja mereka dan aktif bergereja. Bahkan kemudian terlibat dalam pelayanan remaja di gereja mereka.

3. Pemahaman Alkitab dalam Pemuridan Kontekstual.

Ada generasi milenial yang berhenti dari praktik membaca Zodiak karena isi ramalan tidak sesuai keinginan dan harapan bahkan ada peringatan yang membahayakan dirinya sehingga memilih berhenti. Tetapi baru menyadari hal itu dosa disertai alasannya dan harus mempercayakan hidup kepada Tuhan Yesus saja karena mengikuti Pemuridan Kontekstual Kelompok Tumbuh Bersama Kontekstual (KTBK) di sekolahnya. Pembelajaran Firman Allah di dalam KTBK dibawah bimbingan seorang pemimpin kelompok membuatnya dapat memahami dengan jelas alasan-alasan Alkitab mengapa orang Kristen tidak boleh membaca ramalan Zodiak. Sebaliknya hanya mau mengandalkan Tuhn Yesus saja. Bahan-bahan studi kitab yang dipejajari dalam KTBK yaitu Surat 1 Yohanes untuk memantapkan pemahaman tentang status sebagai anak-anak Allah dan Surat Kolose untuk menolong petumbuhan rohani.

KTBK adalah suatu model pemuridan yang beranggotakan 3-6 orang untuk belajar memahami Firman Allah, saling mengontrol di antara anggota agar taat pada Allah dan melipatgandakan pemimpin untuk membentuk KTBK baru. Misi KTBK agar semua anggota bertumbuh sampai dewasa penuh seperti Kristus. Praktik belajar Firman dalam KTBK menerapakan eksegesa Alkitab secara induktif dan kontekstual. Bahan KTBK merupakan studi tiap Kitab dalam Alkitab. Pertanyaan-pertanyaan dalam KTBK meliputi pertanyaan observasi teks, interpretasi teks dan aplikasi masa kini. Dibawah arahan dan ketrampilan memimpin dari pemimpin KTBK, semua anggota akan mendiskusikan Firman Alkitab secara interaktif karena karena memang bahannya dirancang agar terjadi diskusi. Demikian pula jumlah anggota 3-6 orang menjamin semuanya dapat terlibat aktif. Kebenaran final yang dipegang semua anggota KTBK adalah apa yang dikatakan oleh Alkitab itu sendiri37.

\footnotetext{
37 Timotius Haryono and Yuliati, Pemuridan Kontekstual (Surakarta: Yayasan Gamaliel, 2018).
} 


\section{Pola Apologetika Dialogis-Klarifikatif Kepada Generasi Milenial yang Terpapar Zodiak Online}

Mencermati data wawancara dan data literatur tampak bahwa praktik zodiak yang dilakukan generasi milenial, dipicu oleh rasa ingin tahu yang tinggi, sikap terbuka dan semangat mencoba hal-hal baru terutama karena difasilitasi oleh kemudahan teknologi. Kreatifitas media online dalam menyajikan zodiak dengan ruang interaksi dialogis yang terbuka antara host dan konsumen memiliki daya pikat yang kuat karena sesuai dengan rasa, bahasa dan alam pikir generasi melineal (kontekstual). Sehingga terjadi gradasi dimana berawal hanya sekedar mencoba-coba, kemudian terpikat bahkan akhirnya dapat menjadi kelompok dominat-hegemonic. Pertemanan berbasis media sosial juga berdampak besar terhadap laju perluasan praktik zodiak. Bahkan mereka dapat melakukan hal-hal yang senafas dengan praktik zodiac dalam bentuk yang lain misalnya perdukunan dan praktik spriritisme. Sehingga diperlukan suatu pola pelayanan yang memungkinkan terjadinya percakapan dua arah (dialogis) diantara pelayan dan generasi milenial berbasis relasi kelompok pertemanan yang akrab dan pemenuhan kebutuhan rohani yang menyeluruh, baik itu pertobatan dengan Kristus (personal encounter) dan perjumpaan kuasa (power encounter) terkait dengan okultisme dan spiritisme.

Bagi generasi milenial yang masih mampu menimbamg antara benar dan salah serta membedakan yang baik dan buruk (negotiated reading), penolakan terhadap zodiak hanya bisa terjadi apabila mereka mendapat pengajaran tentang kebenaran yang kokoh sehingga dapat mereka pergunakan sebagai sumber nilai untuk menolak praktif zodiak. Namun apabila ada masukan nilai-nilai yang tidak alkitabiah, akan berdampak mereka terbawa arus sesuai pengajaran yang diterima. Karena itu perlu pengajaran kebenaran Alkitab yang gamblang (truth encounter) ${ }^{38}$ sehingga akan menjernihkan pemahaman yang keruh, meluruskan yang bengkok artinya tidak sesuai dengan kehendak Allah serta tegas menolak zodiak disertai alasan mendasar (klarifikatif).

Sementara itu bagi generasi milenial yang menolak zodiak (oppositional reading), perlu menyediakan ruang diskusi terbuka dengan mereka untuk mengetahui alasan penolakan terhadap zodiak. Dalam rangka mengoreksi alasan penolakan yang salah dan menggantinya dengan alasan yang alkitabiah. Sedangkan bagi mereka yang menolak dengan dasar alkitabiah lebih diteguhkan dengan kebenaran Firman Allah sehingga mampu mempertanggungjawabkan jati diri kekristenannya dalam seluruh aspek hidup dihadapan teman-temannya (moral encounter). Mereka juga perlu diperlengkapi dengan ketrampilan untuk menjelaskan kebenaran Alkitab kepada teman-teman yang terikat dengan zodiak agar meninggalkannya. Serta ketrampilan untuk membentuk

${ }^{38}$ Kawangmani, "Pola Apologetika Kontekstual Untuk Memberitakan Kabar Baik Kepada Suku Jawa Wong Cilik," 70. 
kelompok pertemanan rohani diantara gerenerasi untuk bertumbuh dalam Firman Allah, bersaksi dan melayani.

Data lapangan menunjukan bahwa kualifikasi pelayan kepada generasi milenial yang terpapar zodiak meliputi para orangtua Kristen, para hamba Tuhan dan pemimpin kelompok pemuridan. Orangua dengan wibawanya sebagai imam keluarga bertanggungjawab mengajarkan kebenaran Alkitab agar anak-anaknya menolak zodiak. Memang pendekatan pengajaran yang bersifat satu arah dan tanpa alasan-alasan teologis yang jelas bisa saja membawa hasil yaitu anak berhenti dari zodiak. Tetapi tidak memuaskan rasa ingin tahu mereka. Mereka perlu mendapat penjelasan terkait alasan ketidaksetujuan Allah terjadap zodiac disertai landasan Firman Tuhan. Oleh karena itu orangtua perlu mengembangkan pelayanan yang dialogis-klarifikatif dengan anak-anak mereka. Sementara bagi pelayan Tuhan, perlu menyediakan waktu untuk membangun kedekatan dan perhatian yang akrab dengan generasi milenial baik secara personal maupun kolektif sehingga mereka dapat terbuka dan tanpa canggung menceriterakan persoalan hidup mereka. Dan melaluimya kebenaran Alkitab yang menjawab kebutuhan generasi milenial akan identitas diri, harga diri, arah, tujuan dan makna hidup yang tersedia di dalam Yesus Kristus dapat dikomunikasikan secara kontekstual. Sementara potensi pemimpin kelompok pertumbuhan rohani seperti KTBK dan Komsel perlu mengkader para pemimpin dengan pemahaman yang alkitabiah terkait zodiak. Sehingga akan mampu mengarahkan semua anggota untuk mengerti Firman Allah dengan benar dan utuh serta siap mempertanggung-jawabkannya dalam seluruh aspek hidup.

Berita Akitab yang sudah dipergunakakan dalam pelayanan oleh para hamba Tuhan selama ini kepada generasi milenial yang terpapar zodiak diambil secara ayatiah (hand pick), tetap memiliki kuasa transformative dan menghasilkan pertobatan serta komitmen untuk berhenti berzodiak. Ditambah dengan anjuran membaca Injil Yohanes dan Surat 1 Yohanes sebagai bahan follow up pasca pertobatan. Namun menimbang konteks generasi milenial yang memiliki rasa ingin tahu yang besar, maka lebih jelas dan utuh apabila dalam pelayanan menggunakan suatu bagian Alkitab yang menjelaskan berbagai aspek terkait zodiak. Surat Kolose menyediakan suatu perspektif yang utuh terkait isu gnostisisme termasuk di dalamnya zodiak (astrologi) yang viral di media online dewasa ini. Sebagaimana jemaat Kolose baik itu orangtua, generasi muda dan anak-anak yang terpapar gnostisisme beserta varian bidat lainnya dikoreksi secara apologetis-klarifikatif melalui surat Kolose, maka apologetika klarafikatif rasul Paulus tersebut relevan untuk diaplikasikan dalam konteks generasi milenial yang terpapar zodiak online.

Berangkat dari analisa di atas, maka menurut penulis pelayanan kepada generasi milenial yang terpapar zodiak online sangat efektif dan kontekstual menerapkan "Pola 
Apologetika Dialogis-Klarifikatif". Tujuh elemen yang diperhatikan yaitu: pertama, konteks. Generasi milenial memiliki karakteristik tersendiri dibandingkan dengan generasi lainnya, malangnya manifestasi Gnostisisme dalam wujud ramalan Zodiak online dengan kreatifitas penyajiannya di media internet memiliki daya pikat yang kuat. Oleh karena itu pengenalan kepada generasi ini secara mendalam sangat diperlukan untuk mengefektifkan pelayanan.

Kedua, kualifikasi apologet. Apologet kepada generasi milenial yang terpapar zodiak adalah orangtua Kristen, para hamba Tuhan dan pemimpin kelompoak pemuridan KTBK dan Komsel yang memiliki spiritualitas dan moralitas yang unggul. Semua apologet harus memahami konteks generasi milenial yang terpapar zodiak serta kesadaran panggilan berapologetika dengan komitmen yang tinggi. Oleh karena praktik astrologi juga terkait erat dengan okultisme dan spiritisme maka apologet perlu menundukan diri dan bergantung sepenuhnya kepada pimpinan Roh Kudus.

Ketiga, masalah apologetika. Isu utama apologetika kepada generasi milenial yang terpapar zodiak adalah, "Bagaimana pandangan iman Alkitab tentang ramalan Zodiak?" Oleh karena itu apologet harus memiliki jawaban yang alkitabiah. Namun harus juga memahami hal-hal lain yang dapat menjadi pemicu dan melatarbelakangi generasi milenial terlibat praktik zodiak. Ketrampilan mengidentifikasi persoalan yang tersembunyi akan menghasilkan penyelesaian masalah secara holistik.

Keempat, area pijakan bersama (Commond ground). Pelayanan apologet kepada generasi milenial yang terpapar zodiak dapat berangkat dari kesamaan pengalaman melakukan zodiak sebagai common ground. Apologet yang melayani sebagai pemimpin kelompok pemuridan (KTBK) atau Komsel dapat menggunakan status sebagai sesama orang beragama Kristen sebagai common ground. Tegasnya ketrampilan apologet untuk menciptakan common ground akan melancarkan proses komunikasi yang ideal dengan kaum milenial.

Kelima, isi apologetika. Isi apologetika yaitu 15 pokok apologetika klarifikatif

Paulus kepada jemaat Kolose yang terpapar gnostisisme sebagai berikut:

1. Pengalaman rohani sejati tentang keutamaan Kristus dalam Injil (1:1-8).

2. Pengembangan pengalaman rohani sejati tentang keutamaan Kristus dalam Injil (1:9-12)

3. Keutamaan dan keunikan Kristus dalam Penebusan (1:13-14).

4. Keutamaan dan kemahakuaan Kristus dalam dalam penciptaan (1:15-17).

5. Keutamaan dan keagungan Kristus dalam jemaat (1:18-23).

6. Keutamaan dan kewibaaan Kristus dalam pelayanan (1:24-29, 2:1-5).

7. Keunggulan Kristus atas astrologi (2:6-10).

8. Keunggulan Sunat Kristus atas Hukum Sunat manusia (Ritualisme) (2:11-17).

9. Keunggulan Kristus atas Legalisme, Mistisisme dan Asketisisma (2:18-23). 
10. Pertanggungjawaban hidup Kristen berbasis keutamaan dan keunggulan Kristus dalam aspek personal holiness (3:1-4).

11. Pertanggungjawaban hidup Kristen berbasis keutamaan dan keunggulan Kristus dalam aspek Transformasi karakter ilahi (3:5-17).

12. Pertanggungjawaban hidup Kristen berbasis keutamaan dan keunggulan Kristus dalam aspek keluarga (3:18-21).

13. Pertanggungjawaban hidup Kristen berbasis keutamaan dan keunggulan Kristus dalam aspek Profesi (3:22-4:1).

14. Pertanggungjawaban hidup Kristen berbasis keutamaan dan keunggulan Kristus dalam aspek persekutuan dan kesaksian orang percaya (4:2-4).

15. Pertanggungjawaban hidup Kristen berbasis keutamaan dan keunggulan Kristus dalam konteks global (4:5-6).

Keenam, bentuk pelaksanaan Apologetika Dialogis-Klarifikatif. Orangtua sebagai apologet dapat menggunakan bentuk ibadah keluarga secara teratur setiap minggu untuk membahas isi apologetika Paulus dalam surat Kolose tersebut. Sedangkan para hamba Tuhan dapat menggunakan pendekatan apologetika dari pribadi ke pribadi secara Dialogis-Klarifikatif. Dalam hal ini pelayan dapat bertemu langsung (tatap muka) maupun melalui media komunikasi WA, Video Call, dan lainnya yang kontekstual dengan mereka. Sedangkan bentuk pelaksanaan dengan apologet para pemimpin KTBK atau Komsel dapat menggunakan bahan $\mathrm{KTBK}^{39}$ dan sarana kelompok yang sudah ada atau dengan membentuk terlebih dahulu KTBK atau Komsel. Pelaksanaan dapat melalui pertemuan secara fisik dengan semua anggota atau melalai media pertemuan online seprti Zoom dan lainnya. Bentuk pelayanan lain yaitu melalui tulisan atau bentuk publikasi lain di media internet dengan memberikan ruang untuk commen atau diskusi dengan netizen. Bentuk pelayanan ini memiliki jangkauan luas sehingga kebenaran Firman Allah dapat wartakan sampai ke seluruh penjuru dunia.

Ketujuh, sifat pelaksanaan apologetika yaitu Dialogis-Klarifikatif. Apologetika Kristen tidak dimaksukankan untuk mencapai kemenangan di pihak apologet dan kalah dipihak yang dilayani (win-lose) tetapi agar kebenaran Allah itu terkomunikasikan dengan sederhana dan jelas dan ditegakkan bersama (win-win). Proses berapologetika yang dialogis dan memberi ruang seluas-luasnya kepada semua pihak untuk secara terbuka mempercakapkan kebenaran dan mendialogkannya dengan konteks itu yang diupayakan untuk diwujudkan. Seiring dengan itu bagian-bagian Firman Tuhan diberikan penjelasan secara terang-benderang (truth encounter) sehingga dipahami, diinsyafi dan dimaknai dalam hidup. Sehingga pada gilirannya ada keputusan hidup untuk berubah yaitu mau meninggalkan praktik zodiak dan memusatkan hidup

\footnotetext{
${ }^{39}$ Timotius Haryono and Soleman Kawangmani, Seri KTBK Bertumbuh Ke Arah Kristus (Surakarta: Yayasan Gamaliel, 2016), 1-34.
} 
hanya pada Yesus Kristus saja yang terutama dan unggul atas astrologi dan segalagalanya di alam semesta ini dan mempertanggungjawabkannya dalam seluruh aspek kehidupannya.

\section{Kesimpulan}

Generasi milenial yang terpapar zodiak online dapat dilayani secara efektif dengan mengaplikasikan pola Apologetika Dialogis-Klarifikatif. Tujuh alemen apologetika Dialogis-Klarifikatif yaitu pengenalan konteks, kualifikasi apologet, masalah apologetika, area pijakan bersama, isi apologetika, bentuk pelaksanaan dan sifat pelaksanaan apologetika dialogis-klarifikatif yang dipadukan dalam implementasinya akan membawa generasi milenial yang terpapar zodak online untuk menjadikan Kristus yang terutama dan terunggul dalam seluah aspek kehidupan.

\section{Referensi}

Adimihardja, Kusnaka. Metode Penelitian Sosial : Suatu Teknik Penelitian Bidang Kesejahteraan Sosial Dan Ilmu Sosial Lainnya. Edited by Jan Budhi. Edisi ke-8. Bandung: PT Remaja Rosdakarya Offset, 2011.

Afriadi, Arie, and Dendi Pratama. "Simbol Zodiak Pada Motif Ornamen Kumudawati Pura Mangkunenagaran.” Visual Heritage: Jurnal Kreasi Seni dan Budaya 1, no. 03 (2019): 174-179.

Archiantia, Puti. “Memprediksi Kreativitas Generasi Millenial Di Tempat Kerja." Jurnal Ilmiah Penelitian Psikologi: Kajian Empiris \& Non-Empiris 3, no. 2 (2017): 61-68.

Barclay, William. Pemahaan Alkitab Setiap Hari Surat Filipi, Kolose, I \& 2 Tesalonika. Jakarta: BPK Gunung Mulia, 1999.

Cahyowati, Lina, and Estiarto Wahyu Sumirat. "Aplikasi Ramalan Bintang Berbasis Multimedia." Speed-Sentra Penelitian Engineering dan Edukasi 2, no. 1 (2012).

Drane, John. Memahami Perjanjian Baru. Jakarta: BPK Gunung Mulia, 1996.

Grath, Alister E. Mc. Apologetika Dasar : Bagaimana Menolong Para Pencari Kebenaran Dan Orang-Orang Skeptis Untuk Percaya Pada Iman Kristen. Malang: Gandum Mas, 2017.

Haryono, Timotius, and Soleman Kawangmani. Seri KTBK Bertumbuh Ke Arah Kristus. Surakarta: Yayasan Gamaliel, 2016.

Haryono, Timotius, and Daniel Fajar Panuntun. "Model Apologetika Kreatif-Klarifikasi Dalam Mengomunikasikan Kristus Kepada Remaja Usia Pertengahan (15-18 Th) Melalui Media Youtube." Jurnal Penelitian Sekolah Tinggi Teologi Gamaliel 6, no. 1 (2018).

Haryono, Timotius, and Yuliati. Pemuridan Kontekstual. Surakarta: Yayasan Gamaliel, 2018.

J. D. Douglas. Ensiklopedi Alkitab Masa Kini Jilid I. Jakarta: Yayasan Komunikasi Bina Kasih/OMF, 2003.

Juditha, Christiany. "Fenomena Trending Topic Di Twitter: Analisis Wacana Twit \#Savehajilulung." Jurnal Penelitian Komunikasi dan Pembangunan 16, no. 2 (2015): 138-154.

Kawangmani, Soleman. "Pola Apologetika Kontekstual Untuk Memberitakan Kabar Baik Kepada Suku Jawa Wong Cilik." Gamaliel : Teologi praktika 1, no. 2 (2019): 278-279. Lalo, Kalfaris. "Menciptakan Generasi Milenial Berkarakter Dengan Pendidikan Karakter 
Guna Menyongsong Era Globalisasi." Ilmu Kepolisian 12, no. 2 (2018): 68-75.

LightGivers. "\#CANCER Di Februari 2020." Askfm. Last modified 2020. Accessed April 27, 2020. https://ask.fm/LightGivers.

Lumintang, Stevri Indra Danik Astuti Lumintang. Theologia Penelitian Dan Penelitian Theologis Science-Ascience Serta Metodologinya. Jakarta: Geneva Insani Indonesia, 2016.

M. Purwatma. "Tantangan Gnostik Bagi Hidup Beriman Masa Kini.” Orientasi Baru 21, no. 2 (2012).

Meier, Justin, and Stephen Austin. "Generation Y in the Workforce: Managerial Challenges." The Journal of Human Resource and Adult Learning 6, no. 1 (2010).

Panuntun, Daniel Fajar. "Misi Apologetika Kristen Online Di Era Diruspsi." Apostolos 2, no. 1 (2019).

___. "The Social Media Phenomenon Of Satire Account @Gerejapalsu In The Movement Of Holistic Pneumatology In Mission." Jurnal Gamaliel : Teologi Praktika 2, no. 1 (2020).

Permana, Yuda, and Agfianto Eko Putra. "Aplikasi Astrologi (Zodiak) Pada Perangkat Genggam Dengan Menggunakan Teknologi J2me; Application Astrological( Zodiac) On Handheld Device Using J2me Technology.” Universita Gadjah Mada, 2010.

Retnayu Prasetyanti, and Sisman Prasetyo. "Generasi Millennial Dan Inovasi Jejaring Demokrasi Teman Ahok." Jurnal Polinter 3, no. 1 (2017): 44-52.

Rosa, Teofani Dela. "Analisis Resepsi Pembaca Ramalan Zodiak di Ask Fm Lightgivers." Universitas Diponegoro Semarang, 2016.

S.S. Wira Kurniawati. "Wacana Ramalan Zodiak Dalam Media Cetak Berbahasa Indonesia." Universita Gadjah Mada, 2017.

Walidah, Iffah Al. "Tabayyun Di Era Generasi Millenial.” Jurnal Living Hadis 2, no. 2 (2018): 317.

Wibowo, Megawati Hadi, A. J. Soehardjo, and S.Sn Budi Prasetyadi. "Perancangan Buku Ilustrasi 12 Zodiak Dan Karakteristiknya Untuk Remaja Putri Usia 12-17 Tahun.” Jurnal DKV Adiwarna 1, no. 2 (2013): 11.

Widiastuti, Vika, and Rosiana Chozanah. "Mengapa Milenial Banyak Yang Tertarik Dengan Horoskop?" Suara.Com. Last modified 2019. Accessed March 26, 2020. https://www.suara.com/lifestyle/2019/07/19/185000/mengapa-milenialbanyak-yang-tertarik-dengan-horoskop.

Widjana, Doreen. Surat Kolose. 3rd ed. Bandung: LLB, 1999.

Yolanda, Dwiyuni Evi, Isti Mulayani, and M Januar Ibnu Adham. "Pengaruh Generasi Muda Millenial Terhadap Karakter Interaksi." Journal of Chemical Information and Modeling 53, no. 9 (2013): 1689-1699. 